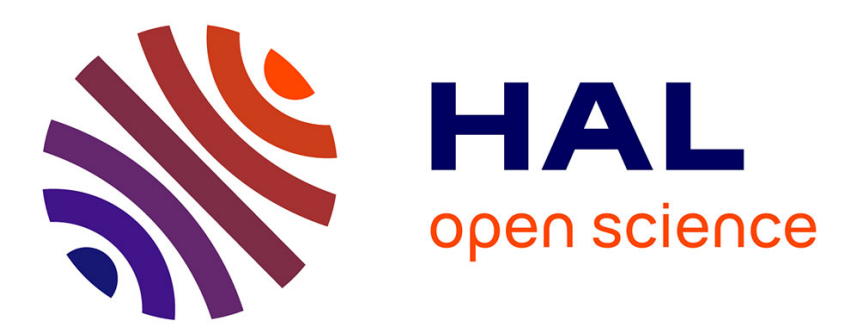

\title{
Prevalence and risk factors of discomfort in infants with severe bronchiolitis
}

\author{
Justine Leboucher Berlendis
}

\section{To cite this version:}

Justine Leboucher Berlendis. Prevalence and risk factors of discomfort in infants with severe bronchiolitis. Human health and pathology. 2021. dumas-03355879

\section{HAL Id: dumas-03355879 https://dumas.ccsd.cnrs.fr/dumas-03355879}

Submitted on 27 Sep 2021

HAL is a multi-disciplinary open access archive for the deposit and dissemination of scientific research documents, whether they are published or not. The documents may come from teaching and research institutions in France or abroad, or from public or private research centers.
L'archive ouverte pluridisciplinaire HAL, est destinée au dépôt et à la diffusion de documents scientifiques de niveau recherche, publiés ou non, émanant des établissements d'enseignement et de recherche français ou étrangers, des laboratoires publics ou privés. 


\section{UCA \\ FACULTÉ \\ DE MÉDECINE Uriversitite Alpes}

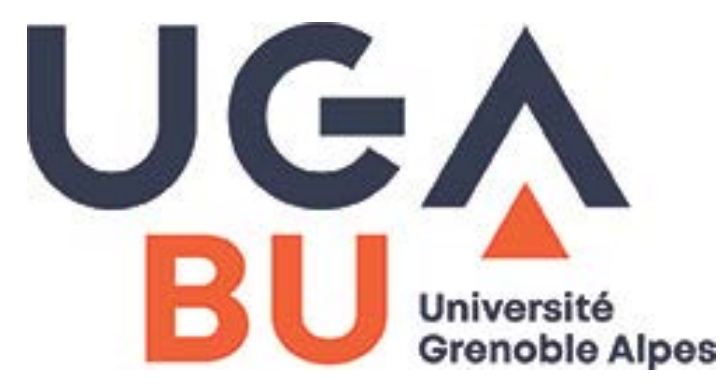

\section{AVERTISSEMENT}

Ce document est le fruit d'un long travail approuvé par le jury de soutenance.

La propriété intellectuelle du document reste entièrement celle du ou des auteurs. Les utilisateurs doivent respecter le droit d'auteur selon la législation en vigueur, et sont soumis aux règles habituelles du bon usage, comme pour les publications sur papier : respect des travaux originaux, citation, interdiction du pillage intellectuel, etc.

Il est mis à disposition de toute personne intéressée par l'intermédiaire de l'archive ouverte DUMAS (Dépôt Universitaire de Mémoires Après Soutenance).

Si vous désirez contacter son ou ses auteurs, nous vous invitons à consulter la page de DUMAS présentant le document. Si l'auteur l'a autorisé, son adresse mail apparaîtra lorsque vous cliquerez sur le bouton « Détails » (à droite du nom).

Dans le cas contraire, vous pouvez consulter en ligne les annuaires de l'ordre des médecins, des pharmaciens et des sagesfemmes.

Contact à la Bibliothèque universitaire de Médecine Pharmacie de Grenoble : bump-theses@univ-grenoble-alpes.fr 


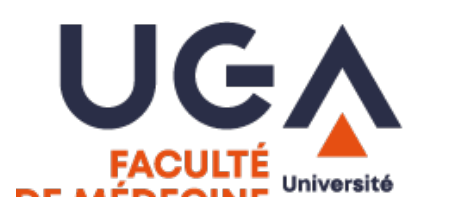

DE MÉDECINE Grenoble Alpes

Année : 2021

\title{
PREVALENCE AND RISK FACTORS OF DISCOMFORT IN INFANTS WITH SEVERE BRONCHIOLITIS
}

\author{
THÈSE \\ POUR LE DIPLÔME D’ÉTAT DE DOCTEUR EN MÉDECINE \\ SPÉCIALITÉ : PÉDIATRIE
}

Par Mme Justine LEBOUCHER (née BERLENDIS)

[Données à caractère personnel]

THÈSE SOUTENUE PUBLIQUEMENT À LA FACULTÉ DE MÉDECINE DE GRENOBLE

Le 23 septembre 2021

DEVANT LE JURY COMPOSÉ DE :

Président du jury :

M. le Professeur Thierry DEBILLON

Membres :

M. le Professeur Dominique PLANTAZ

M. le Docteur Guillaume MORTAMET (directeur de thèse)

Mme le Docteur Églantine HULLO

L'UFR de Médecine de Grenoble n'entend donner aucune approbation ni improbation aux opinions émises dans les thèses ; ces opinions sont considérées comme propres à leurs auteurs. 


\section{UCA}

DE MÉDECINE Université

Doyen de la Faculté : Pr. Patrice MORAND

Année 2020-2021

ENSEIGNANTS DE L'UFR DE MEDECINE

\begin{tabular}{|c|c|c|}
\hline CORPS & NOM-PRENOM & Discipline universitaire \\
\hline PU-PH & ALBALADEJO Pierre & Anesthésiologie-réanimation et médecine péri-opératoire \\
\hline PU-PH & APTEL Florent & Ophtalmologie \\
\hline PU-PH & ARVIEUX-BARTHELEMY Catherine & Chirurgie viscérale et digestive \\
\hline PU-PH & BAILLET Athan & Rhumatologie \\
\hline PU-PH & BARONE-ROCHETTE Gilles & Cardiologie \\
\hline PU-PH & BAYAT Sam & Physiologie \\
\hline MCF Ass.MG & BENDAMENE Farouk & Médecine Générale \\
\hline PU-PH & BENHAMOU Pierre-Yves & Endocrinologie, diabète et maladies métaboliques \\
\hline PU-PH & BERGER François & Biologie cellulaire \\
\hline MCU-PH & BIDART-COUTTON Marie & Biologie cellulaire \\
\hline PU-PH & BLAISE Sophie & Chirurgie vasculaire ; médecine vasculaire \\
\hline PR Ass. Méd. & BOILLOT Bernard & \\
\hline MCU-PH & BOISSET Sandrine & Bactériologie-virologie ; Hygiène hospitalière \\
\hline PU-PH & BONAZ Bruno & Gastroentérologie ; hépatologie ; addictologie \\
\hline PU-PH & BONNETERRE Vincent & Médecine et santé au travail \\
\hline PU-PH & BOREL Anne-Laure & Nutrition \\
\hline PU-PH & BOSSON Jean-Luc & Biostatistiques, informatique médicale et technologies de communication \\
\hline MCU-PH & BOTTARI Serge & Biologie cellulaire \\
\hline PR Ass.MG & BOUCHAUD Jacques & Médecine Générale \\
\hline PU-PH & BOUGEROL Thierry & Psychiatrie d'adultes \\
\hline PU-PH & BOUILLET Laurence & Médecine interne ; gériatrie et biologie du vieillissement ; addictologie \\
\hline MCU-PH & BOUSSAT Bastien & Epidémiologie, économie de la santé et prévention \\
\hline PU-PH & BOUZAT Pierre & Anesthésiologie-réanimation et médecine péri-opératoire \\
\hline PU-PH émérite & BRAMBILLA Christian & Pneumologie \\
\hline PU-PH émérite & BRAMBILLA Elisabeth & Anatomie et cytologie pathologiques \\
\hline MCU-PH & BRENIER-PINCHART Marie Pierre & Parasitologie et mycologie \\
\hline PU-PH & BRICAULT Ivan & Radiologie et imagerie médicale \\
\hline PU-PH & BRICHON Pierre-Yves & Chirurgie thoracique et cardiovasculaire \\
\hline MCU-PH & BRIOT Raphaël & Thérapeutique-médecine de la douleur ; Addictologie \\
\hline PU-PH émérite & CAHN Jean-Yves & Hématologie \\
\hline PU-PH émérite & CARPENTIER Patrick & Chirurgie vasculaire, médecine vasculaire \\
\hline PR Ass.MG & CARRILLO Yannick & Médecine Générale \\
\hline PU-PH & CESBRON Jean-Yves & Immunologie \\
\hline PU-PH & CHABARDES Stephan & Neurochirurgie \\
\hline PU-PH & CHABRE Olivier & Endocrinologie, diabète et maladies métaboliques \\
\hline PU-PH & CHAFFANJON Philippe & Anatomie \\
\hline MCF Ass.MG & CHAMBOREDON Benoît & Médecine Générale \\
\hline PU-PH & CHARLES Julie & Dermato-vénéréologie \\
\hline MCF Ass.MG & CHAUVET Marion & Médecine Générale \\
\hline PU-PH & CHAVANON Olivier & Chirurgie thoracique et cardiovasculaire \\
\hline
\end{tabular}

Mis à jour le 4 septembre 2020

Page 1 sur 4 


\begin{tabular}{|c|c|c|}
\hline CORPS & NOM-PRENOM & Discipline universitaire \\
\hline PU-PH & CHIQUET Christophe & Ophtalmologie \\
\hline PU-PH & CHIRICA Mircea & Chirurgie viscérale et digestive \\
\hline PU-PH & CINQUIN Philippe & Biostatistiques, informatique médicale et technologies de communication \\
\hline MCU-PH & CLAVARINO Giovanna & Immunologie \\
\hline PU-PH & COHEN Olivier & Histologie, embryologie et cytogénétique \\
\hline PU-PH & COURVOISIER Aurélien & Chirurgie infantile \\
\hline PU-PH & COUTTON Charles & Génétique \\
\hline PU-PH & COUTURIER Pascal & Médecine interne ; gériatrie et biologie du vieillissement ; addictologie \\
\hline PU-PH & CRACOWSKI Jean-Luc & Pharmacologie fondamentale; pharmacologie clinique ; addictologie \\
\hline PU-PH & DEBATY Guillaume & Médecine d'Urgence \\
\hline PU-PH & DEBILLON Thierry & Pédiatrie \\
\hline PU-PH & DECAENS Thomas & Gastroentérologie ; hépatologie ; addictologie \\
\hline PR Ass. Méd. & DEFAYE Pascal & Cardiologie \\
\hline PU-PH & DEGANO Bruno & Pneumologie ; addictologie \\
\hline PU-PH & DEMATTEIS Maurice & Pharmacologie fondamentale ; pharmacologie clinique ; addictologie \\
\hline PU-PH émérite & DEMONGEOT Jacques & Biostatistiques, informatique médicale et technologies de communication \\
\hline MCU-PH & DERANSART Colin & Physiologie \\
\hline PU-PH & DESCOTES Jean-Luc & Urologie \\
\hline PU-PH & DETANTE Olivier & Neurologie \\
\hline MCU-PH & DIETERICH Klaus & Génétique \\
\hline MCU-PH & DOUTRELEAU Stéphane & Physiologie \\
\hline MCU-PH & DUMESTRE-PERARD Chantal & Immunologie \\
\hline PU-PH & EPAULARD Olivier & Maladies infectieuses; Maladies tropicales \\
\hline PU-PH & ESTEVE François & Biophysique et médecine nucléaire \\
\hline MCU-PH & EYSSERIC Hélène & Médecine légale et droit de la santé \\
\hline PU-PH & FAUCHERON Jean-Luc & Chirurgie viscérale et digestive \\
\hline MCU-PH & FAURE Julien & Biochimie et biologie moléculaire \\
\hline PU-PH & FERRETTI Gilbert & Radiologie et imagerie médicale \\
\hline PU-PH & FEUERSTEIN Claude & Physiologie \\
\hline PU-PH & FONTAINE Éric & Nutrition \\
\hline PU-PH & FRANCOIS Patrice & Epidémiologie, économie de la santé et prévention \\
\hline MCU-MG & GABOREAU Yoann & Médecine Générale \\
\hline PU-PH & GARBAN Frédéric & Hématologie ; Transfusion \\
\hline PU-PH & GAUDIN Philippe & Rhumatologie \\
\hline PU-PH & GAVAZZI Gaétan & Médecine interne ; gériatrie et biologie du vieillissement ; addictologie \\
\hline PU-PH & GAY Emmanuel & Neurochirurgie \\
\hline MCU-PH & GILLOIS Pierre & Biostatistiques, informatique médicale et technologies de communication \\
\hline PU-PH & GIOT Jean-Philippe & Chirurgie plastique, reconstructrice et esthétique ; Brûlologie \\
\hline MCU-PH & GRAND Sylvie & Radiologie et imagerie médicale \\
\hline PU-PH émérite & GRIFFET Jacques & Chirurgie infantile \\
\hline MCU-PH & GUZUN Rita & Nutrition \\
\hline PU-PH & HAINAUT Pierre & Biochimie et biologie moléculaire \\
\hline PU-PH émérite & HALIMI Serge & Nutrition \\
\hline PU-PH & HENNEBICQ Sylviane & Biologie et médecine du développement et de la reproduction ; gynécologie médicale \\
\hline PU-PH & HOFFMANN Pascale & Gynécologie-obstétrique ; gynécologie médicale \\
\hline PU-PH émérite & HOMMEL Marc & Neurologie \\
\hline PU-MG & IMBERT Patrick & Médecine Générale \\
\hline
\end{tabular}




\begin{tabular}{|c|c|c|}
\hline CORPS & NOM-PRENOM & Discipline universitaire \\
\hline PU-PH émérite & JouK Pierre-Simon & Génétique \\
\hline $\mathrm{PU}-\mathrm{PH}$ & KAHANE Philippe & Physiologie \\
\hline MCU-PH & KASTLER Adrian & Radiologie et imagerie médicale \\
\hline PU-PH & KRAINIK Alexandre & Radiologie et imagerie médicale \\
\hline PU-PH & LABARERE José & Epidémiologie, économie de la santé et prévention \\
\hline MCU-PH & LABLANCHE Sandrine & Endocrinologie, diabète et maladies métaboliques \\
\hline MCU-PH & LANDELLE Caroline & Bactériologie - virologie ; Hygiène hospitalière \\
\hline PU-PH & LANTUEJOUL Sylvie & Anatomie et cytologie pathologiques \\
\hline PR Ass. Méd. & LARAMAS Mathieu & Cancérologie ; radiothérapie \\
\hline MCU-PH & LARDY Bernard & Biochimie et biologie moléculaire \\
\hline $\mathrm{MCU}-\mathrm{PH}$ & LE GOUELLEC LE PISSART Audrey & Biochimie et biologie moléculaire \\
\hline PU-PH & LECCIA Marie-Thérèse & Dermato-vénéréologie \\
\hline MCF Ass.MG & LEDOUX Jean-Nicolas & Médecine Générale \\
\hline PU-PH émérite & LETOUBLON Christian & Chirurgie viscérale et digestive \\
\hline PU-PH & LEVY Patrick & Physiologie \\
\hline PU-PH & LONG Jean-Alexandre & Urologie \\
\hline MCU-PH & LUPO Julien & Bactériologie-virologie ; Hygiène hospitalière \\
\hline PU-PH & MAIGNAN Maxime & Médecine d'urgence \\
\hline PU-PH & MAITRE Anne & Médecine et santé au travail \\
\hline MCU-PH & MALLARET Marie-Reine & Bactériologie - virologie ; Hygiène hospitalière \\
\hline MCU-PH & MARLU Raphaël & Hématologie ; Transfusion \\
\hline PR Ass. Méd. & MATHIEU Nicolas & Gastroentérologie ; hépatologie ; addictologie \\
\hline MCU-PH & MAUBON Danièle & Parasitologie et mycologie \\
\hline PU-PH & MAURIN Max & Bactériologie-virologie ; Hygiène hospitalière \\
\hline MCU-PH & MC LEER Anne & Histologie, embryologie et cytogénétique \\
\hline MCU-PH & MONDET Julie & Histologie, embryologie et cytogénétique \\
\hline PU-PH & MORAND Patrice & Bactériologie-virologie ; Hygiène hospitalière \\
\hline PU-PH & MOREAU-GAUDRY Alexandre & Biostatistiques, informatique médicale et technologies de communication \\
\hline PU-PH & MORO Elena & Neurologie \\
\hline PU-PH & MORO-SIBILOT Denis & Pneumologie ; addictologie \\
\hline MCU-PH & MORTAMET Guillaume & Pédiatrie \\
\hline PU-PH & MOUSSEAU Mireille & Cancérologie ; radiothérapie \\
\hline PU-PH émérite & MOUTET François & Chirurgie plastique, reconstructrice et esthétique ; brûlologie \\
\hline MCF Ass.MG & ODDOU Christel & Médecine Générale \\
\hline PR Ass. Méd. & ORMEZZANO Olivier & Cardiologie \\
\hline MCU-PH & PACLET Marie-Hélène & Biochimie et biologie moléculaire \\
\hline PU-PH & PAILHE Régis & Chirurgie orthopédique et traumatologie \\
\hline PU-PH & PALOMBI Olivier & Anatomie \\
\hline PU-PH & PARK Sophie & Hématologie ; Transfusion \\
\hline PU-PH & PASSAGGIA Jean-Guy & Anatomie \\
\hline PR Ass.MG & PAUMIER-DESBRIERES Françoise & Médecine Générale \\
\hline PU-PH & PAYEN DE LA GARANDERIE Jean-François & Anesthésiologie-réanimation et médecine péri-opératoire \\
\hline MCU-PH & PAYSANT François & Médecine légale et droit de la santé \\
\hline MCU-PH & PELLETIER Laurent & Biologie cellulaire \\
\hline PU-PH & PELLOUX Hervé & Parasitologie et mycologie \\
\hline PU-PH & PEPIN Jean-Louis & Physiologie \\
\hline PU-PH & PERENNOU Dominique & Médecine physique et de réadaptation \\
\hline
\end{tabular}




\begin{tabular}{|c|c|c|}
\hline CORPS & NOM-PRENOM & Discipline universitaire \\
\hline PU-PH & PERNOD Gilles & Chirurgie vasculaire ; Médecine vasculaire \\
\hline PU-PH & PIOLAT Christian & Chirurgie infantile \\
\hline $\mathrm{PU}-\mathrm{PH}$ & PISON Christophe & Pneumologie ; Addictologie \\
\hline PU-PH & PLANTAZ Dominique & Pédiatrie \\
\hline PU-PH & POIGNARD Pascal & Bactériologie-virologie ; Hygiène hospitalière \\
\hline PU-PH & POLACK Benoît & Hématologie ; Transfusion \\
\hline PU-PH & POLOSAN Mircea & Psychiatrie d'adultes ; Addictologie \\
\hline PU-PH & RAMBEAUD Jean-Jacques & Urologie \\
\hline PU-PH & RAY Pierre & Biologie et médecine du développement et de la reproduction ; gynécologie médicale \\
\hline PR Ass. Méd. & RECHE Fabian & Chirurgie viscérale et digestive \\
\hline MCU-PH & RENDU John & Biochimie et biologie moléculaire \\
\hline MCU-PH émérite & RIALLE Vincent & Biostatistiques, informatique médicale et technologies de communication \\
\hline PU-PH & RIETHMULLER Didier & Gynécologie-obstétrique ; gynécologie médicale \\
\hline PU-PH & RIGHINI Christian & Oto-rhino-laryngologie \\
\hline PU-PH émérite & ROMANET Jean Paul & Ophtalmologie \\
\hline PU-PH & ROSTAING Lionel & Néphrologie \\
\hline PU-PH & ROUSTIT Matthieu & Pharmacologie fondamentale ; pharmacologie clinique ; addictologie \\
\hline MCU-PH & ROUX-BUISSON Nathalie & Biochimie et biologie moléculaire \\
\hline PR Ass.MG & ROYER DE VERICOURT Guillaume & Médecine Générale \\
\hline PU-PH émérite & SARAGAGLIA Dominique & Chirurgie orthopédique et traumatologie \\
\hline MCU-PH & SATRE Véronique & Génétique \\
\hline PU-PH & SAUDOU Frédéric & Biologie cellulaire \\
\hline PU-PH & SCHMERBER Sébastien & Oto-rhino-laryngologie \\
\hline PU-PH & SCHWEBEL Carole & Médecine intensive-réanimation \\
\hline PU-PH & SCOLAN Virginie & Médecine légale et droit de la santé \\
\hline MCU-PH & SEIGNEURIN Arnaud & Epidémiologie, économie de la santé et prévention \\
\hline PU-PH émérite & STAHL Jean-Paul & Maladies infectieuses; Maladies tropicales \\
\hline PU-PH & STANKE Françoise & Pharmacologie fondamentale ; pharmacologie clinique ; addictologie \\
\hline MCU-PH & STASIA Marie-José & Biochimie et biologie moléculaire \\
\hline PU-PH & STURM Nathalie & Anatomie et cytologie pathologiques \\
\hline PU-PH & TAMISIER Renaud & Physiologie \\
\hline PU-PH & TERZI Nicolas & Médecine intensive-réanimation \\
\hline PU-PH & THEVENON Julien & Génétique \\
\hline MCU-PH & TOFFART Anne-Claire & Pneumologie ; Addictologie \\
\hline PU-PH & TONETTI Jérôme & Chirurgie orthopédique et traumatologie \\
\hline PU-PH & TOUSSAINT Bertrand & Biochimie et biologie moléculaire \\
\hline PU-PH & VALMARY-DEGANO Séverine & Anatomie et cytologie pathologiques \\
\hline PU-PH & VANZETTO Gérald & Cardiologie \\
\hline PU-PH & VUILLEZ Jean-Philippe & Biophysique et médecine nucléaire \\
\hline PU-PH & WEIL Georges & Epidémiologie, économie de la santé et prévention \\
\hline PU-PH & ZAOUI Philippe & Néphrologie \\
\hline PU-PH émérite & ZARSKI Jean-Pierre & Gastroentérologie ; hépatologie ; addictologie \\
\hline
\end{tabular}

PU-PH : Professeur des Universités - Praticiens Hospitaliers

MCU-PH : Maître de Conférences des Universités - Praticiens Hospitaliers

PU-MG : Professeur des Universités de Médecine Générale

MCU-MG : Maitre de Conférences des Universités de Médecine Générale

PR Ass. Méd. : Professeur des Universités Associé de Médecine

PR Ass.MG : Professeur des Universités Associé de Médecine Générale

MCF Ass.MG : Maître de Conférences Associé de Médecine Générale 


\section{REMERCIEMENTS}

Un grand merci au Dr Guillaume MORTAMET d'avoir accepté d'encadrer ce travail. Tu as su, avec bienveillance, être à l'écoute de mes nombreuses questions et m'apporter ton aide qui a été indispensable à la rédaction de cette thèse. J'ai appris énormément de choses grâce à toi.

Merci aux membres de mon jury : le Pr Thierry DEBILLON, le Pr Dominique PLANTAZ et le Dr Eglantine HULLO pour votre accompagnement au cours de mon cursus, et pour avoir accepté d'évaluer cette thèse. Votre avis est très important et vos remarques seront sans aucun doute enrichissantes.

Merci aux différentes équipes médicales et paramédicales que j’ai pu côtoyer pendant mon internat. Chaque jour à vos côtés fût un plaisir, j'ai beaucoup appris grâce à vous.

Merci à mes nombreux co-internes, avec qui j'ai pu passer une partie plus ou moins longue de mon parcours. Une mention spéciale pour notre super promo de pédiatrie : Laure, Laurianne, Justine, Dalila, Séverine, Quentin et Ellen. Je n'aurais pas pu rêver mieux, vous êtes géniaux !

Merci à mes amis les plus proches, Blandine, Benoit, Valentin, qui sont présents depuis toujours. Malgré la distance et le temps qui passe, on s'entend toujours comme si on s'était quitté hier.

Merci à ma famille ainsi que ma belle-famille. Il est impossible de citer tout le monde, mais je suis fière d'en faire partie. C'est plaisant d'être un membre d'une famille qui malgré parfois les divergences d'opinion, reste soudée dans les moments importants. 
Merci à toi maman. Tu as toujours tout sacrifié pour tes enfants sans même qu'on ne te le demande. C'est entièrement grâce à toi que j'en suis là aujourd'hui. Mes réussites sont les tiennes, tu nous as porté à bout de bras toute notre vie, sois fière de toi tu le mérites.

Merci à vous, Elodie et Florian. Je suis heureuse d'être votre petite sœur. Je sais que quoi qu'il arrive, vous répondrez présents si besoin comme vous l'avez toujours fait.

Merci à toi mon amour. Toi qui partages ma vie depuis longtemps déjà. Toi qui me pousses toujours à donner le meilleur de moi-même, y compris quand je perds espoir. On a déjà traversé de nombreuses épreuves ensemble qui ne nous ont rendu que plus forts. Pleins de beaux jours sont encore à venir. Je t'aime.

Enfin à vous deux. Mes garçons, mes amours, mes petits bonheurs.

A toi mon Yanis, mon grand garçon. Toi qu'on a tant espéré, toi qui as le sourire aux lèvres depuis le premier jour. Mon petit soleil, ma canaille. Toi à qui on a déjà trop souvent dit qu'on doit travailler.

A toi mon Maxime, mon bébé d'amour, mon calinou. Toi qui peux me redonner toute l'énergie du monde dans un simple câlin ou un grand sourire. Toi qui arrives à nous faire comprendre tellement de choses avec un simple regard.

Ce travail il est pour vous, j'espère qu'un jour vous en serez fiers. Je suis heureuse d'être votre maman. Je vous aime fort. 


\section{TABLE DES MATIÈRES}

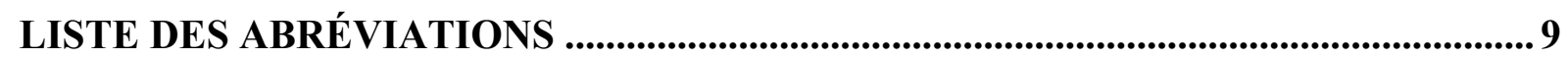

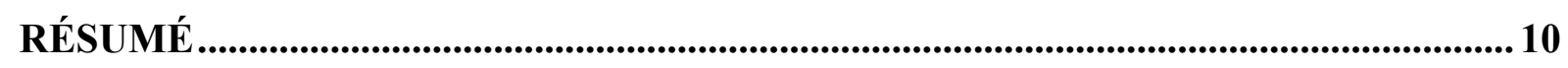

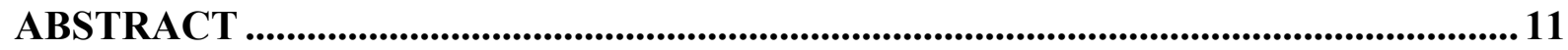

I. BACKGROUND ………....................................................................................... 12

II. METHOD.................................................................................................................. 14

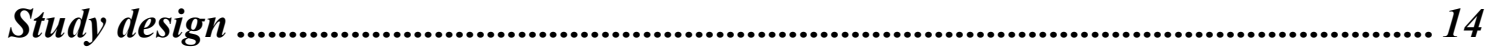

Study population .............................................................................................................. 14

Clinical management (local protocol),....................................................................... 14

Endpoint ............................................................................................................... 15

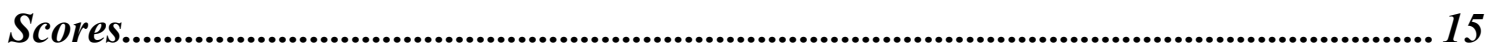

Data collection ............................................................................................................... 16

Statistical analysis.............................................................................................. 16

III. RESULTS.................................................................................................................... 17

Description of the population ...................................................................................... 17

Prevalence of discomfort ................................................................................................. 19

Risk factors of discomfort.......................................................................................... 20

IV. DISCUSSION .......................................................................................................... 23

V. CONCLUSION ...................................................................................................... 25

BIBLIOGRAPHY …………………................................................................................ 27

APPENDIX ............................................................................................................................ 30

APPENDIX 1 : EDIN scale......................................................................................... 30

APPENDIX 2 : Wang score ........................................................................................... 31

SERMENT D'HIPPOCRATE ................................................................................................32 


\section{LISTE DES ABRÉVIATIONS}

BiPAP $=$ Biphasic Positive Airway Pressure

$\mathrm{CPAP}=$ Continuous Positive Airway Pressure

EDIN scale $=$ Échelle de Douleur et d'Inconfort du Nouveau-né

$\mathrm{FiO}_{2}=$ Inspired Fraction of oxygen

HFNC $=$ High Flow Nasal Cannula

$\mathrm{IQR}=$ Interquartile Range

LOS $=$ Length of stay

m-WCAS = modified Wood's Clinical Asthma Score

$\mathrm{NIV}=$ Non Invasive Ventilation

$\mathrm{NG}$ tube $=$ nasogastric tube

OHD = Oxygénothérapie Haut Débit

$\mathrm{PEP}=$ Positive Expiratory airway Pressure

PICU $=$ Pediatric Intensive Care Unit

$\mathrm{PvCO}_{2}=$ Partial venous Carbon dioxide pressure

$\mathrm{RSV}=$ Respiratory Syncytial Virus

$\mathrm{SpO}_{2}=$ Oxygen saturation

$\mathrm{SD}=$ Standard Deviation 


\section{RÉSUMÉ}

Objectifs : Déterminer la prévalence de l'inconfort chez les enfants atteints de bronchiolite sévère ayant une ventilation non invasive et identifier ses potentiels facteurs de risque.

Méthode : Nous avons conduit durant une période de 5 mois une étude rétrospective et monocentrique. Tous les nourrissons de moins de 12 mois admis en réanimation pédiatrique pendant la période d'étude avec un diagnostic de bronchiolite et aidés par une ventilation non invasive (incluant l'Oxygénothérapie Haut Débit (OHD), la CPAP (Continuous Positive Airway Pressure) ou la BiPAP (Bilevel Positive Airway Pressure)) durant leur séjour en réanimation ont été inclus. L'inconfort a été évalué en utilisant l'échelle d'EDIN (Échelle de Douleur et d'Inconfort du Nouveau-né), recueillie par les infirmières toutes les 4 à 6 heures durant l'hospitalisation.

Résultats : 91 enfants (age médian 34 jours [19-55], 52 (57\%) garçons) ont été inclus dans notre étude. Trente-un (34\%), 35 (39\%) et 23 (25\%) avaient à l'admission un support par OHD, CPAP et BiPAP respectivement. Les patients avaient un score d'EDIN médian à 2.9 (SD 2.3), 2.3 (SD 2.1) et 2.3 (SD 2.0) aux jours 1, 2 et 3 respectivement. Il n'y avait pas de différence concernant les données démographiques, biologiques et cliniques en fonction du degré d'inconfort au premier jour. Aux jours 1 et 2 , les patients ayant une BiPAP avaient un score d'EDIN supérieur aux autres patients (3.3 (SD 2.5) contre 2.6 (SD 2.2) à J1, et 2.9 (SD 2.1) contre 2.3 (SD 2.2) à J2, les deux avec $\mathrm{p}<0.001)$ (Figure 2A).

Conclusion : Les patients ayant une bronchiolite sévère sont peu inconfortables durant les trois premiers jours de réanimation. En comparaison aux patients avec OHD ou CPAP, les patients nécessitant une BiPAP semblent être plus inconfortables, alors que nous n'avons pas trouvé de corrélation entre le niveau d'inconfort et le degré de détresse respiratoire.

Mots clés : bronchiolite - douleur - inconfort - détresse respiratoire - réanimation 


\begin{abstract}
Objectives: To assess the prevalence of discomfort in infants with severe bronchiolitis supported by noninvasive ventilation and to identify its potential risk factors.

Methods : A single-center retrospective observational study conducted over a 5-month period. All the infants aged $\leq 12$ months admitted to the Pediatric Intensive Care Unit (PICU) during the study period with a clinical diagnosis of bronchiolitis and supported by any type of noninvasive ventilation (including High- Flow Nasal Cannula (HFNC), Continous Positive Airway Pressure (CPAP) or Bilevel Positive Airway Pressure (BiPAP)) during ICU stay were included. Discomfort was assessed using the EDIN (Echelle de Douleur et d'Inconfort du Nouveau-né) scale, collected by nurses every 4 to 6 hours during PICU hospitalization.

Results : 91 infants (median age 34 days [Interquartile IQR 19-55], 52 (57\%) boys) were included in our study. Thirty-one (34\%), 35 (39\%) and 23 (25\%) were supported by HNCF, CPAP and BiPAP at admission, respectively.

Overall, patients had a median EDIN score at 2.9 (SD 2.3), 2.3 (SD 2.1) and 2.3 (SD 2.0) on day 1, 2 and 3, respectively. There was no difference in the demographic, biological and clinical data according to the degree of discomfort on day 1 . On day 1 and 2, patients supported by BiPAP had a higher EDIN score compared to other patients (3.3 (SD 2.5) versus 2.6 (SD 2.2) on day 1 and 2.9 (SD 2.1) versus 2.3 (SD 2.2) on day 2, both $p<0.001$ ) (Figure 2A).

Conclusion : Patients with severe bronchiolitis and supported by any type of noninvasive ventilation have a low degree of discomfort during the first three days of ICU stay. As compared to patients supported by HFNC or CPAP, patients requiring bilevel noninvasive ventilation seems to have a higher degree of discomfort, while we found no correlation between the level of discomfort and the degree of respiratory distress.
\end{abstract}

Keywords : bronchiolitis, pain, discomfort, acute respiratory failure, intensive care unit 


\section{BACKGROUND}

Acute bronchiolitis is a common viral infection that affects a large number of children each winter in western countries ${ }^{1}$. The most severe forms of bronchiolitis can lead to acute respiratory failure, and therefore admission in pediatric intensive care unit (PICU). Ventilatory support is commonly used in patients with bronchiolitis admitted in PICU, especially noninvasive ventilation ${ }^{2}$. High flow nasal cannula (HFNC), continuous positive airway pressure (CPAP) and bilevel positive airway pressure ventilation (BiPAP) are increasingly used in patients with severe acute bronchiolitis ${ }^{3}$. In acute settings, noninvasive ventilation (including HFNC, CPAP and BiPAP) aims to improve gas exchange, decrease work of breathing and improve patients' comfort $^{4}$. Its benefits have been demonstrated in both physiological ${ }^{5}$ and clinical $^{6}$ studies. However, the use of any type of noninvasive ventilation may also constitute a factor of discomfort, especially in acute settings ${ }^{7}$. An inappropriate interface ${ }^{8}$ with an excessive tightening ${ }^{9}$, the presence of unintentional leaks, the presence of gastric dilatation ${ }^{10}$ or the occurrence of asynchrony ${ }^{11}$ may constitute significant sources of discomfort.

In addition, bronchiolitis is likely to cause significant discomfort in infants for several reasons: because of the symptoms of bronchiolitis (cough, fever, rhinitis, respiratory distress), because of feeding difficulties, and because of the care given to these critically ill children (mechanical ventilation, nasal suctioning, physiotherapy $)^{4}$. As well, the PICU environment may be a source of stress in children and its parents.

In preterm infants, it has been shown that repeated pain or stress can be associated with impaired neurodevelopment, and can lead to anxiety behaviors in childhood ${ }^{12}$. Since bronchiolitis affect young infants, we may assume that discomfort may have the same consequences in this population. 
For all these reasons, management of discomfort is crucial in patients with bronchiolitis-related respiratory failure, especially since discomfort can be responsible for noninvasive ventilation failure ${ }^{13}$. However, in contrast to the extensive literature on the management of patients with severe bronchiolitis, there is paucity of data on patient comfort and the potential effect of ventilatory mode. In this context, this study aims to assess the prevalence of discomfort in infants with severe bronchiolitis supported by noninvasive ventilation and to identify its potential risk factors 


\section{METHOD}

\section{Study design}

This single-center retrospective observational study was conducted over a 5-month period from November 2019 to April 2020, in a 16-bed PICU of a tertiary pediatric center. The nurse-tochildren ratio is $1: 2$ or $1: 3$ at all times in our PICU.

The study was approved by the regional research committee (Comité d'Ethique du Centre d'Investigation Clinique de Clermont-Ferrand, France, IRB 5891, September, 2021) and follows the STROBE guidelines. Parents of patients had been informed and non-opposition had been searched before data collection. No written consent was required.

\section{Study population}

All the infants aged $\leq 12$ months, admitted to the PICU during the study period with a clinical diagnosis of bronchiolitis and supported by any type of noninvasive ventilation (including HFNC, CPAP or BiPAP) during ICU stay were included. The admission criteria in PICU were left at the discretion of the attending physician without any local protocol. There were no exclusion criteria.

\section{Clinical management (local protocol)}

A step-up ventilator strategy was used according to the increase in patient severity, led by physicians: 1/ HFNC, 2/ CPAP, 3/ BiPAP and 4/ invasive ventilation. CPAP and BiPAP were performed using an ICU ventilator (Evita V500 ${ }^{\mathrm{TM}}$, Drager ${ }^{\circledR}$, Germany or Servo $\mathrm{I}^{\mathrm{TM}}$ and $\mathrm{U}^{\mathrm{TM}}$, Maquet ${ }^{\circledR}$, Solna, Sweden) with a facial or nasal interface while HFNC was started at a flow rate of $2 \mathrm{~L} / \mathrm{kg} / \mathrm{min}$ with an ICU ventilator (Evita V500 ${ }^{\mathrm{TM}}$, Draeger ${ }^{\circledR}$, Germany), or with a 
specific device (Airvo ${ }^{\mathrm{TM}}$, Fisher and Paykel ${ }^{\circledR}$, Auckland, New Zealand). In our pediatric center, HFNC is not commonly used in pediatric wards.

In our local practice, patients with bronchiolitis did not receive any sedative drug and the use of painkillers was based only on nurses' clinical judgment (no written protocol). EDIN (Echelle de Douleur et d'Inconfort du Nouveau-né) scale is commonly used to assess discomfort in this population (see below). An EDIN score $>8$ and/or a fever $>38.5^{\circ}$ commonly led to the use of paracetamol. In our unit, the parents were allowed and encouraged to stay with their child continuously in order to reassure their infant.

\section{Endpoint}

We used as primary endpoint the degree of discomfort. A priori, we defined the most uncomfortable patients those with a mean EDIN score superior to the 50th percentile of the entire cohort on day 1, i.e., the half of patients with the most important discomfort.

\section{Scores}

To assess the severity of the respiratory distress syndrome, Wang score ${ }^{14}$ was collected by nurses every 4 to 6 hours. It ranges from 0 (i.e., no respiratory distress) to 12 (i.e., high level of respiratory distress). EDIN scale ${ }^{15}$ was collected by nurses every 4 to 6 hours during PICU hospitalization. EDIN is a neonatal pain and discomfort scale including five behavioral indicators: facial activity, body movements, quality of sleep, quality of contact, and consolability. It ranges from 0 (i.e., no discomfort) to 15 (i.e., high level of discomfort). An EDIN score $>8$ commonly lead to the administration of analgesics. 


\section{Data collection}

To describe the population, we collected demographic (age, sex and comorbidities) and clinical data during the PICU stay. Respiratory comorbidity was defined as any clinically significant neonatal lung disease, such as bronchopulmonary dysplasia. Clinical data at admission were the Wang severity score, hemodynamic and respiratory parameters, ventilatory mode and settings and medical treatment. Biological data on admission, including venous $\mathrm{pH}$ and venous carbon dioxide $(\mathrm{PvCO} 2)$ were also gathered. All infants were screened for respiratory syncytial virus (RSV) at admission.

The EDIN score and the use of analgesics (including paracetamol, nalbuphine or opioids, alone or in combination) during the first three days of PICU stay were collected, as well as the feeding methods (oral or enteral) and mode of ventilation. Partial and complete enteral feeding were defined as intakes lower or higher than $100 \mathrm{ml} / \mathrm{kg} /$ day, respectively. Finally, the duration of ventilatory support and the PICU and hospital lengths of stay were analyzed.

\section{Statistical analysis}

Descriptive data were presented as number/percentages for categorical data and median (with interquartile range, IQR) or mean (with standard deviation SD) values for continuous data. Differences in categorical variables were tested using the Chi-square or Fisher's exact test. Differences in continuous variables were assessed by Mann-Whitney test or analysis of variance test after verification of the eligibility conditions. Pearson's correlation coefficient (R) and determination coefficient $\left(\mathrm{R}^{2}\right)$ were used to evaluate the correlation between the Wang and EDIN scores at admission. P values of less than .05 were considered significant. All statistical analyses were performed using Jamovi (Jamovi 1.6, Sydney, Australia). 


\section{RESULTS}

\section{Description of the population}

A total of 91 patients were included in the study (median age 34 days [Interquartile IQR 1955], 52 (57\%) boys). Eight (9\%) were born preterm (median gestational age 39 [37-40] weeks). Patients included had a median Wang score of 8 [6-9] at admission. Thirty-one (34\%), 35 (39\%) and $23(25 \%)$ were supported by HNCF, CPAP and BiPAP at admission, respectively. Two patients had no respiratory support at admission but were supported during their stay. Patients' characteristics are detailed in Table 1. 
Table 1: Patients' characteristics

\begin{tabular}{|c|c|}
\hline Factors & Total $\mathbf{N}=91$ \\
\hline \multicolumn{2}{|l|}{ Demographic data } \\
\hline Male, n (\%) & $52(57 \%)$ \\
\hline Age, days, median & $34[19-55]$ \\
\hline Weight, kg, median & $4.2[3.6-4.8]$ \\
\hline \multicolumn{2}{|l|}{ Comorbidities } \\
\hline Respiratory, n (\%) & $1(1)$ \\
\hline Prematurity, n (\%) & $8(9)$ \\
\hline \multicolumn{2}{|l|}{ Type of alimentation } \\
\hline Breast feeding exclusive, $\mathrm{n}(\%)$ & $41(45)$ \\
\hline Formula, $\mathrm{n}(\%)$ & $35(38)$ \\
\hline Both, n (\%) & $15(17)$ \\
\hline \multicolumn{2}{|l|}{ Clinical data at admission } \\
\hline Wang score, median & $8[6-9]$ \\
\hline Respiratory rate, breaths/min, median & $43[35-53]$ \\
\hline Heart rate, beats/min, median & $158[143-170]$ \\
\hline Body temperature, ${ }^{\circ} \mathrm{C}$, median & $37.0[36.7-37.5]$ \\
\hline Witnessed apnea, n (\%) & $26(28)$ \\
\hline \multicolumn{2}{|l|}{ Mode of respiratory support at admission } \\
\hline None, n (\%) & $2(2)$ \\
\hline HFNC, n (\%) & $31(34)$ \\
\hline CPAP, n (\%) & $35(39)$ \\
\hline BiPAP, n (\%) & $23(25)$ \\
\hline \multicolumn{2}{|l|}{ Biological data at admission } \\
\hline $\mathrm{pH}$, median & 7.34 [7.30-7.39] \\
\hline $\mathrm{PvCO}_{2}, \mathrm{mmHg}$, median & $54[46-59]$ \\
\hline RSV positive, $\mathrm{n}(\%)$ & $86(93)$ \\
\hline \multicolumn{2}{|l|}{ Equipment at admission } \\
\hline Nasogastric tube, n (\%) & $88(97)$ \\
\hline Peripheral venous catheter, $\mathrm{n}(\%)$ & $83(91)$ \\
\hline \multicolumn{2}{|l|}{ Outcomes } \\
\hline Ventilatory support duration, hours, median & 59 [26-83] \\
\hline PICU LOS, hours, median & $88[54-109]$ \\
\hline Hospital LOS, days, median & $7[6-9]$ \\
\hline
\end{tabular}

Values are given as median with interquartile [IQR] or numbers (\%)

BiPAP: bilevel positive airway pressure; CPAP: continuous positive airway pressure; HFNC: high flow nasal cannula; LOS: length of stay; PICU: pediatric intensive care unit; $\mathrm{PvCO}_{2}$ : partial venous carbon dioxide pressure; $R S V$ : respiratory syncytial virus 


\section{Prevalence of discomfort}

Overall, patients had a mean EDIN score at 2.9 (SD 2.3), 2.3 (SD 2.1) and 2.3 (SD 2.0) on day 1, 2 and 3, respectively (Figure 1A). They received 1.7 (SD 1.8), 1.2 (SD 1.8) and 0.8 (SD 1.4) doses of painkillers on day 1, 2 and 3, respectively (Figure 1B).

Figure 1 : Prevalence of discomfort on the first three days. A - Mean EDIN score. B - Use of painkillers.

A

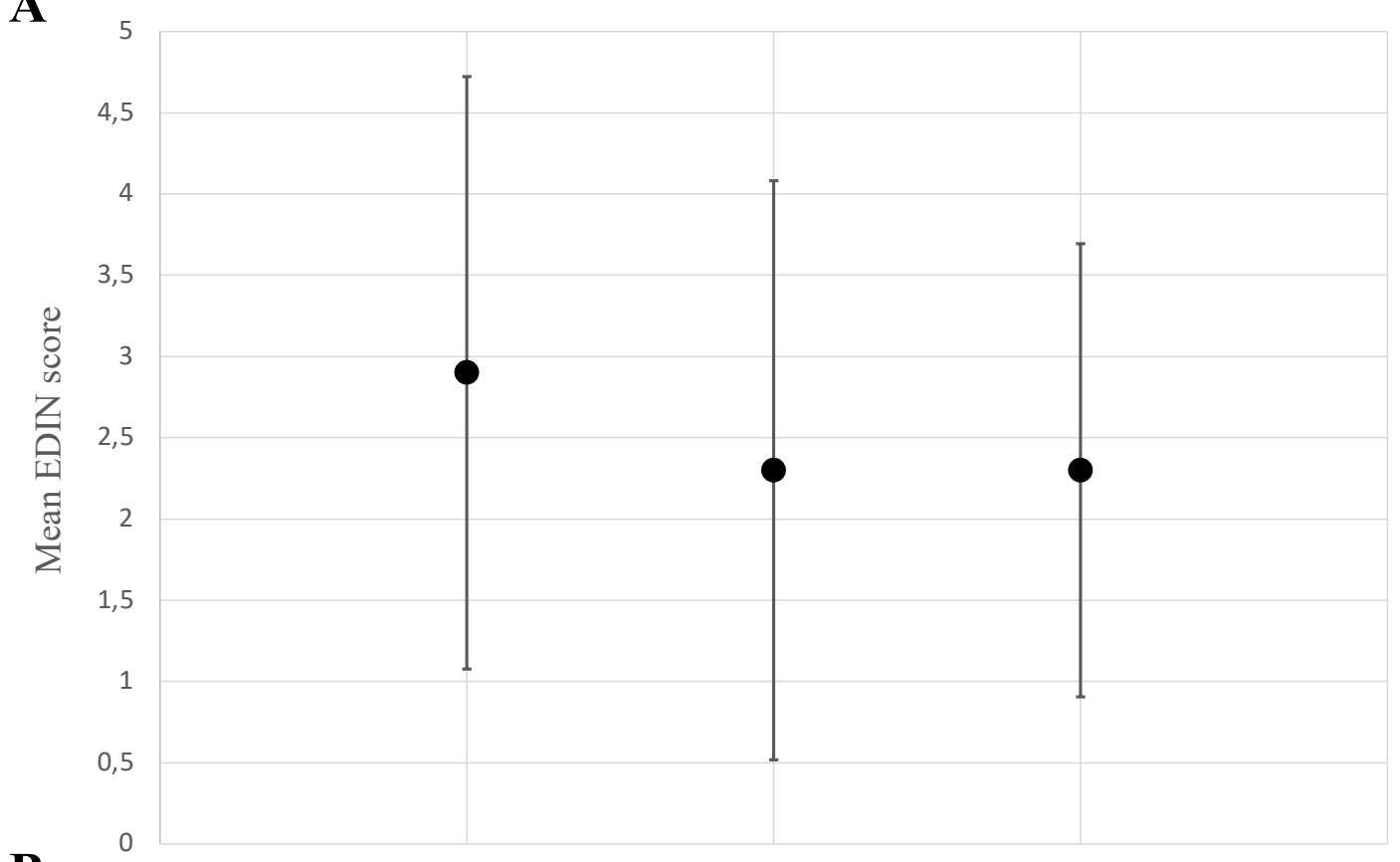

B

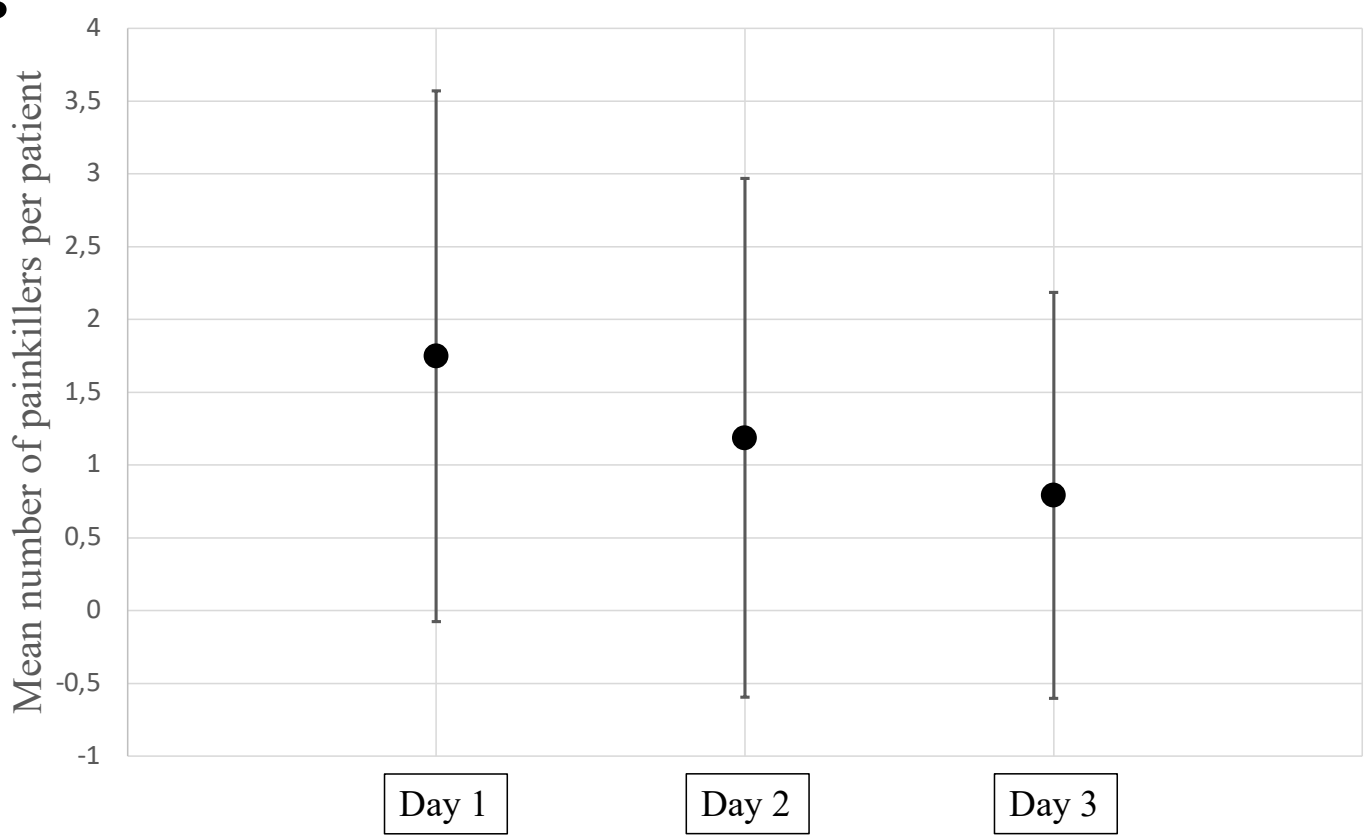




\section{Risk factors of discomfort}

As shown in Table 2, there was no difference in the demographic, biological and clinical data according to the degree of discomfort on day 1. Regarding the outcome, patients with the highest degree of discomfort had a longer duration of ventilation as well as a longer ICU length of stay (68 [55-106] versus 57 [33-79] hours, $p=0.03$, and 94 [65-122] versus 73 [46-101] hours, $\mathrm{p}=0.03$, respectively). The hospital length of stay did not differ between the two groups. 
Table 2: Factors associated with a higher EDIN score on day 1

\begin{tabular}{|c|c|c|c|}
\hline Factors & $\begin{array}{c}\text { The least } \\
\text { uncomfortable } \\
\text { patients } \\
\mathbf{N}=45\end{array}$ & $\begin{array}{c}\text { The most } \\
\text { uncomfortable } \\
\text { patients } \\
N=46\end{array}$ & $\mathbf{p}$ \\
\hline \multicolumn{4}{|l|}{ Demographic data } \\
\hline Male, n (\%) & $27(58)$ & $25(55)$ & 0.59 \\
\hline Age, days, median & $36[20-53]$ & $31[17-54]$ & 0.71 \\
\hline \multicolumn{4}{|l|}{ Discomfort } \\
\hline EDIN on day 1, mean, SD & $1.9(1.9)$ & $3.8(2.3)$ & $<0.01 *$ \\
\hline $\begin{array}{l}\text { Doses of painkillers per patient given on } \\
\text { day } 1, \text { mean, SD }\end{array}$ & $1.2(1.4)$ & $2.2(2.1)$ & $0.02 *$ \\
\hline \multicolumn{4}{|l|}{ Comorbidities } \\
\hline Prematurity, n (\%) & $3(7)$ & $5(11)$ & 0.71 \\
\hline \multicolumn{4}{|l|}{ Clinical data at admission } \\
\hline Wang score, median & $6[5-7]$ & $7[6-8]$ & 0.13 \\
\hline Respiratory rate, breaths/min, median & $49[41-56]$ & $50[41-58]$ & 0.38 \\
\hline Heart rate, beats/min, median & $160[144-170]$ & $157[142-170]$ & 0.59 \\
\hline Body temperature, ${ }^{\circ} \mathrm{C}$, median & $37.0[36.7-37.4]$ & $37.0[36.7-37.6]$ & 0.70 \\
\hline Witnessed apnea, n (\%) & $10(22)$ & $15(33)$ & 0.27 \\
\hline \multicolumn{4}{|l|}{$\begin{array}{l}\text { Mode of respiratory support at } \\
\text { admission }\end{array}$} \\
\hline None, n (\%) & $1(2)$ & $1(2)$ & 1 \\
\hline HFNC, n (\%) & $16(35)$ & $15(33)$ & 0.77 \\
\hline CPAP, n (\%) & $19(42)$ & $16(35)$ & 0.47 \\
\hline BiPAP, n (\%) & $9(20)$ & $14(30)$ & 0.25 \\
\hline Feeding within 2 hours of admission & $13(29)$ & $8(17)$ & 0.2 \\
\hline \multicolumn{4}{|l|}{ Biological data at admission } \\
\hline $\mathrm{pH}$, median & $7.34[7.30-7.37]$ & $7.33[7.28-7.36]$ & 0.50 \\
\hline $\mathrm{PvCO}_{2}, \mathrm{mmHg}$, median & $54[47-59]$ & $50[45-57]$ & 0.23 \\
\hline \multicolumn{4}{|l|}{ Outcomes } \\
\hline $\begin{array}{l}\text { Ventilatory support duration, hours, } \\
\text { median }\end{array}$ & $57[33-79]$ & 68 [55-106] & $0.03 *$ \\
\hline PICU LOS, hours, median & 73 [46-101] & $94[65-122]$ & $0.03 *$ \\
\hline Hospital LOS, hours, median & $7[5-8]$ & $8[6-10]$ & 0.07 \\
\hline
\end{tabular}

Values are given as median with interquartile [IQR] or numbers (\%)

BiPAP: bilevel positive airway pressure; CPAP: continuous positive airway pressure; HFNC: high flow nasal cannula; LOS: length of stay; PICU: pediatric intensive care unit; $\mathrm{PvCO}_{2}$ : partial venous carbon dioxide pressure 
On day 1 and 2, patients supported by BiPAP had a higher EDIN score compared to other patients (3.3 (SD 2.5) versus 2.6 (SD 2.2) on day 1 and 2.9 (SD 2.1) versus 2.3 (SD 2.2) on day 2, both $\mathrm{p}<0.001$ ) (Figure 2A). On day 1 and 2, EDIN score was lower in patients partially or completely fed as compared to other patients (2.6 (SD 2.1) versus 3.2 (SD 2.4) on day 1 and $2.2(\mathrm{SD} 2.0)$ versus $3.2(\mathrm{SD} 2.2)$ on day 2 , both $\mathrm{p}<0.001)$ (Figure $2 \mathrm{~B}$ ).

Figure 2 : Risk factors of discomfort on the first three days. A - Impact of ventilatory support on discomfort. B - Impact of feeding on discomfort.
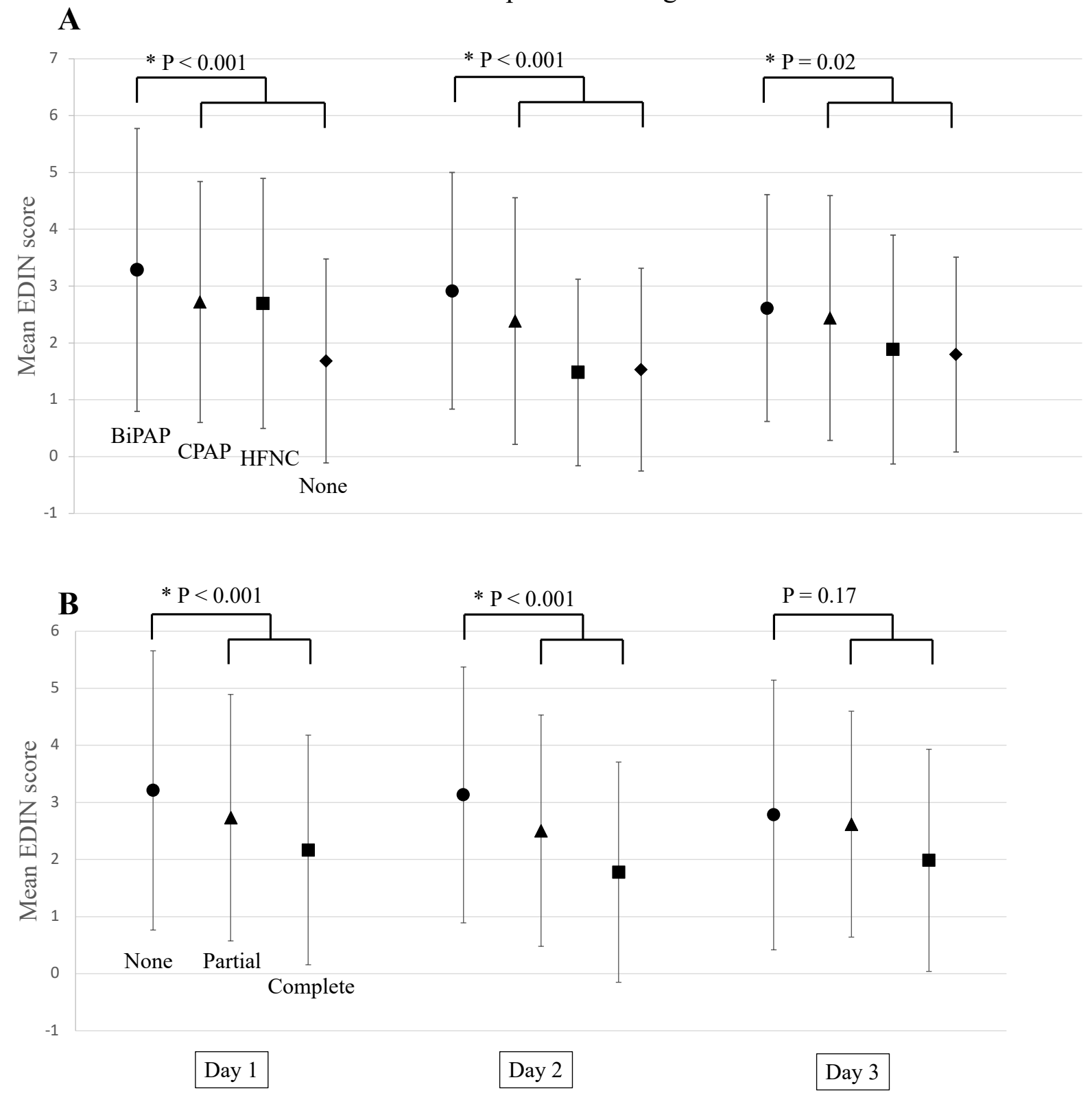

BiPAP: bilevel positive airway pressure; CPAP: continuous positive airway pressure; HFNC: high flow nasal cannula 


\section{DISCUSSION}

We found that patients with severe bronchiolitis and supported by any type of noninvasive ventilation have a low degree of discomfort during the first three days of ICU admission. We did not identify any risk factor for discomfort, but we did find a significant impact of the ventilatory mode on patient comfort.

The management of comfort in patients admitted in PICU is crucial. Poor assessment of the child's comfort during hospitalization can lead to over or underdosing of analgesic treatments, with significant consequences ${ }^{16}$. In our clinical practice, we use EDIN to assess comfort in this population. Despite this scale has been developed and validated in the neonatal population, this method of assessment is commonly used in patients with bronchiolitis ${ }^{17}$.

Overall, we found that infants with severe bronchiolitis had a low degree of discomfort, supporting the benefit of noninvasive ventilation to improve the comfort of patients. Importantly, we found a significant impact of the ventilatory mode on the comfort of patients. Infants supported by bilevel noninvasive ventilation had a higher EDIN mean score as compared to patients supported by other types of ventilatory support. We hypothesize that this is mainly related to a suboptimal patient-ventilator interaction in bilevel mode ${ }^{10,18,19}$. Indeed, the use of pressure support in assisted modes requires both inspiratory and expiratory synchrony, especially in young infants. To reduce asynchrony, the use of Neurally Adjusted Ventilatory Asist (NAVA) have been shown to be helpful in this population ${ }^{20,21}$. As well, we cannot exclude a certain relationship between the severity of the disease and the degree of discomfort as assessed by EDIN score in our study. Since we use BiPAP for the most severe patients in our center, we cannot exclude that those supported by BiPAP were considered more discomfortable because of their severity, despite we did not find any correlation between 
severity of respiratory distress, as assessed by Wang score, and discomfort. Future studies with a larger number of patients are warranted to explore this.

Regarding outcome of patients, we found that patients with the highest degree of discomfort had a longer duration of ventilation as well as a longer ICU length of stay. This support our hypothesis that the most severe patients are also the most uncomfortable, or at least identified as such. Another explanation may be that the most uncomfortable patients could be mistakenly judged as more severe, and thus lead to unnecessary continuation of noninvasive ventilation. This study presents some limitations that should be highlighted. First, it is a single center and retrospective study with a limited number of patients. However, since the management of severe bronchiolitis is likely homogeneous in western countries, we consider our findings as generalizable. Second, we acknowledge that using EDIN score as comfort assessment may be controversial, given its subjectivity. It is true that EDIN was measured at a point in time and not continuously. Validated methods for assessing pain and discomfort in this population are very limited. In addition, EDIN was generally measured when the nurse was providing care to the child, while the infant was awake and stimulated, and not while the child was sleeping. Third, despite we did not find any correlation between the level of discomfort and the degree of respiratory distress, we cannot exclude that the presence of signs of respiratory failure, including signs of respiratory distress and signs of hypercarbia, may impact the comfort assessment. Unfortunately, we did not assess comfort before noninvasive ventilation initiation, and we acknowledge that this would have been relevant to collect such data. Fourth, we did not collect the types and duration of procedures that are likely to cause acute discomfort, like venous punctures, nasogastric tubes insertion or nasal suctioning. Finally, we did not collect the ventilatory parameters, while they may have a strong impact on patient comfort. 


\section{CONCLUSION}

Patients with severe bronchiolitis and supported by any type of noninvasive ventilation have a low degree of discomfort during the first three days of ICU stay. As compared to patients supported by HFNC or CPAP, patients requiring bilevel noninvasive ventilation seems to have a higher degree of discomfort, while we found no correlation between the level of discomfort and the degree of respiratory distress. Future studies with larger numbers of patients are needed to identify patients at high risk for discomfort in order to optimize their management upon admission. 
THÈSE SOUTENUE PAR : LEBOUCHER Justine

TITRE :

Prevalence and risk factors of discomfort in infants with severe bronchiolitis

\section{CONCLUSION :}

Patients with severe bronchiolitis and supported by any type of noninvasive ventilation have a low degree of discomfort during the first three days of ICU stay. As compared to patients supported by HFNC or CPAP, patients requiring bilevel noninvasive ventilation seems to have a higher degree of discomfort, while we found no correlation between the level of discomfort and the degree of respiratory distress. Future studies with larger numbers of patients are needed to identify patients at high risk for discomfort in order to optimize their management upon admission.

\section{VU ET PERMIS D'IMPRIMER}

Grenoble, le : 27/08/2021

LE DOYEN

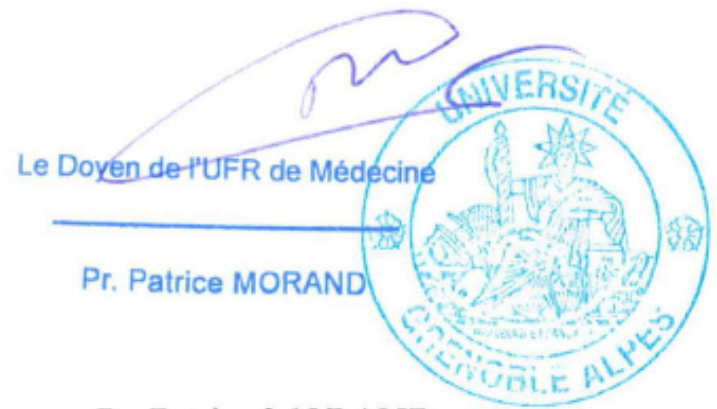

Pr. Patrice MORAND
LE PRÉSIDENT DE LA THÈSE

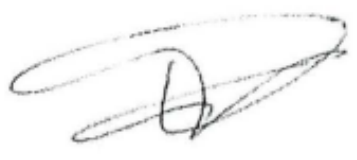

Pr. Thierry DEBILLON

CENTAE HOSPITALIEF .

DE GRENC

$\because$ TAIRE

Service de Médecin un als ,

Réanimation $1:$ :

Pr Th. DEBI _. ON

Chef de Service 


\section{BIBLIOGRAPHY}

1. Fauroux B, Hascoët JM, Jarreau PH, Magny JF, Rozé JC, Saliba E, Schwarzinger M. Risk factors for bronchiolitis hospitalization in infants: A French nationwide retrospective cohort study over four consecutive seasons (2009-2013). PLoS One 2020;15(3):e0229766.

2. Clayton JA, McKee B, Slain KN, Rotta AT, Shein SL. Outcomes of Children With Bronchiolitis Treated With High-Flow Nasal Cannula or Noninvasive Positive Pressure Ventilation. Pediatr Crit Care Med 2019;20(2):128-135.

3. Pelletier JH, Au AK, Fuhrman D, Clark RSB, Horvat C. Trends in Bronchiolitis ICU Admissions and Ventilation Practices: 2010-2019. Pediatrics 2021;147(6).

4. Cuquemelle E, Pham T, Papon JF, Louis B, Danin PE, Brochard L. Heated and humidified high-flow oxygen therapy reduces discomfort during hypoxemic respiratory failure. Respir Care 2012;57(10):1571-1577.

5. Essouri S, Durand P, Chevret L, Balu L, Devictor D, Fauroux B, Tissieres P. Optimal level of nasal continuous positive airway pressure in severe viral bronchiolitis. Intensive Care Med 2011;37(12):2002-2007.

6. Milesi C, Matecki S, Jaber S, Mura T, Jacquot A, Pidoux O, Chautemps N, Novais AR, Combes C, Picaud JC, Cambonie G. $6 \mathrm{cmH} 2 \mathrm{O}$ continuous positive airway pressure versus conventional oxygen therapy in severe viral bronchiolitis: a randomized trial. Pediatr Pulmonol 2013;48(1):45-51.

7. Baudin F, Gagnon S, Crulli B, Proulx F, Jouvet P, Emeriaud G. Modalities and Complications Associated With the Use of High-Flow Nasal Cannula: Experience in a Pediatric ICU. Respir Care 2016;61(10):1305-1310. 
8. Ribeiro DFC, Barros FS, Fernandes BL, Nakato AM, Nohama P. Nasal Prongs: Risks, Injuries Incidence and Preventive Approaches Associated with Their Use in Newborns. J Multidiscip Healthc 2020;13:527-537.

9. Visscher MO, White CC, Jones JM, Cahill T, Jones DC, Pan BS. Face Masks for Noninvasive Ventilation: Fit, Excess Skin Hydration, and Pressure Ulcers. Respir Care 2015;60(11):1536-1547.

10. Lemyre B, Davis PG, De Paoli AG, Kirpalani H. Nasal intermittent positive pressure ventilation (NIPPV) versus nasal continuous positive airway pressure (NCPAP) for preterm neonates after extubation. Cochrane Database Syst Rev 2017;2:CD003212.

11. Vignaux L, Grazioli S, Piquilloud L, Bochaton N, Karam O, Levy-Jamet Y, Jaecklin T, Tourneux P, Jolliet P, Rimensberger PC. Patient-ventilator asynchrony during noninvasive pressure support ventilation and neurally adjusted ventilatory assist in infants and children. Pediatr Crit Care Med 2013;14(8):e357-364.

12. Vinall J, Grunau RE. Impact of repeated procedural pain-related stress in infants born very preterm. Pediatr Res 2014;75(5):584-587.

13. Milesi C, Essouri S, Pouyau R, Liet JM, Afanetti M, Portefaix A, Baleine J, Durand S, Combes C, Douillard A, Cambonie G, Groupe Francophone de Reanimation et d'Urgences P. High flow nasal cannula (HFNC) versus nasal continuous positive airway pressure (nCPAP) for the initial respiratory management of acute viral bronchiolitis in young infants: a multicenter randomized controlled trial (TRAMONTANE study). Intensive Care Med 2017;43(2):209-216.

14. Wang EE, Milner RA, Navas L, Maj H. Observer agreement for respiratory signs and oximetry in infants hospitalized with lower respiratory infections. Am Rev Respir Dis 1992;145(1):106-109. 
15. Debillon T, Zupan V, Ravault N, Magny JF, Dehan M. Development and initial validation of the EDIN scale, a new tool for assessing prolonged pain in preterm infants. Arch Dis Child Fetal Neonatal Ed 2001;85(1):F36-41.

16. Harris J, Ramelet AS, van Dijk M, Pokorna P, Wielenga J, Tume L, Tibboel D, Ista E. Clinical recommendations for pain, sedation, withdrawal and delirium assessment in critically ill infants and children: an ESPNIC position statement for healthcare professionals. Intensive Care Med 2016;42(6):972-986.

17. Fabre C, Panciatici M, Sauvaget E, Tardieu S, Jouve E, Dequin M, Retornaz K, Bartoli JM, Stremler-Le Bel N, Bosdure E, Dubus JC. Real-life study of the role of high-flow nasal cannula for bronchiolitis in children younger than 3 months hospitalised in general pediatric departments. Arch Pediatr 2021;28(1):1-6.

18. Caldarelli V, Borel JC, Khirani S, Ramirez A, Cutrera R, Pepin JL, Fauroux B. Polygraphic respiratory events during sleep with noninvasive ventilation in children: description, prevalence, and clinical consequences. Intensive Care Med 2013;39(4):739-746.

19. Delacroix E, Millet A, Pin I, Mortamet G. Use of bilevel positive pressure ventilation in patients with bronchiolitis. Pediatr Pulmonol 2020;55(11):3134-3138.

20. Christophe M, Julien B, Gilles C. Improving synchrony in young infants supported by noninvasive ventilation for severe bronchiolitis: Yes, we can... so we should! Pediatr Pulmonol 2021;56(2):319-322.

21. Baudin F, Emeriaud G, Essouri S, Beck J, Javouhey E, Guerin C. Neurally adjusted ventilatory assist decreases work of breathing during non-invasive ventilation in infants with severe bronchiolitis. Crit Care 2019;23(1):120. 


\section{APPENDIX}

\section{APPENDIX 1 : EDIN scale}

\begin{tabular}{|c|c|c|}
\hline Indicator & Description & Result \\
\hline Facial activity & $\begin{array}{l}\text { Relaxed facial activity } \\
\text { Transient grimaces with frowning, lip purse and chin quiver or tautness } \\
\text { Frequent grimaces, lasting grimaces } \\
\text { Permanent grimaces resembling crying or blank face }\end{array}$ & $\begin{array}{l}0 \\
1 \\
2 \\
3\end{array}$ \\
\hline $\begin{array}{l}\text { Body } \\
\text { movements }\end{array}$ & $\begin{array}{l}\text { Relaxed body movements } \\
\text { Transient agitation, often quiet } \\
\text { Frequent agitation but can be calmed down } \\
\text { Permanent agitation with contraction of fingers and toes and hypertonia of limbs or } \\
\text { infrequent, slow movements and prostration }\end{array}$ & $\begin{array}{l}0 \\
1 \\
2 \\
3\end{array}$ \\
\hline Quality of sleep & $\begin{array}{l}\text { Falls asleep easily } \\
\text { Falls asleep with difficulty } \\
\text { Frequent, spontaneous arousals, independent of nursing, restless sleep } \\
\text { Sleepless }\end{array}$ & $\begin{array}{l}0 \\
1 \\
2 \\
3\end{array}$ \\
\hline $\begin{array}{l}\text { Quality of } \\
\text { contact with } \\
\text { nurses }\end{array}$ & $\begin{array}{l}\text { Smiles, attentive to voice } \\
\text { Transient apprehension during interactions with nurses } \\
\text { Difficulty communicating with nurses. Cries in response to minor stimulation } \\
\text { Refuses to communicate with nurses. No interpersonal rapport. Moans without } \\
\text { stimulation. }\end{array}$ & $\begin{array}{l}0 \\
1 \\
2 \\
3\end{array}$ \\
\hline Consolability & $\begin{array}{l}\text { Quiet, total relaxation } \\
\text { Calms down quickly in response to stroking or voice, or with sucking } \\
\text { Calms down with difficulty } \\
\text { Disconsolate. Sucks desperately }\end{array}$ & $\begin{array}{l}0 \\
1 \\
2 \\
3\end{array}$ \\
\hline
\end{tabular}

Debillon T. et al, Development and initial validation of the EDIN scale, a new tool for assessing prolonged pain in preterm infants. Archives of Disease in Childhood - Fetal and Neonatal Edition. 1 juill 2001;85(1):36F - 41. 


\section{APPENDIX 2 : Wang score}

\begin{tabular}{|c|c|c|}
\hline Indicator & Description & Score \\
\hline Respiratory rate (breath/min) & $\begin{array}{l}<30 \\
31-45 \\
45-60 \\
>60\end{array}$ & $\begin{array}{l}0 \\
1 \\
2 \\
3\end{array}$ \\
\hline Wheezing & $\begin{array}{l}\text { None } \\
\text { Terminal expiration or only with stethoscope } \\
\text { Entire expiration or audible on expiration without stethoscope } \\
\text { Inspiration and expiration without stethoscope }\end{array}$ & $\begin{array}{l}0 \\
1 \\
2 \\
3\end{array}$ \\
\hline Retractions & $\begin{array}{l}\text { None } \\
\text { Intercostal only } \\
\text { Tracheosternal } \\
\text { Severe with nasal flaring }\end{array}$ & $\begin{array}{l}0 \\
1 \\
2 \\
3\end{array}$ \\
\hline General condition & $\begin{array}{l}\text { Normal } \\
\text { Irritable, lethargic, poor feeding }\end{array}$ & $\begin{array}{l}0 \\
3\end{array}$ \\
\hline
\end{tabular}

\section{Classification :}

- Score from 0 to 3: bronchiolitis without severity criteria.

- Score from 4 to 7 : bronchiolitis of moderate severity.

- Score from 8 to 12 : severe bronchiolitis.

“Observer Agreement for Respiratory Signs and Oximetry in Infants Hospitalized with Lower Respiratory Infections" Wang et al 


\section{SERMENT D'HIPPOCRATE}

\section{Ce serment d'Hippocrate}

Texte revu par l'Ordre des médecins en 2012

\section{6 au moment d'être admis(e) à exercer la médecine, je promets et je jure d'être fidèle aux lois de l'honneur et de la probité.}

Mon premier souci sera de rétablir, de préserver ou de promouvoir la santé dans tous ses éléments, physiques et mentaux, individuels et sociaux.

Je respecterai toutes les personnes, leur autonomie et leur volonté, sans aucune discrimination selon leurétat ou leurs convictions. J'interviendrai pour les protéger si elles sont affaiblies, vulnérables ou menacées dans leur intégrité ou leur dignité. Même sous la contrainte, je ne ferai pas usage de mes connaissances contre les lois de l'humanité.

J'informerai les patients des décisions envisagées, de leurs raisons et de leurs conséquences.

Je ne tromperai jamais leur confiance et n'exploiterai pas le pouvoir hérité des circonstances pour forcer les consciences.

Je donnerai mes soins à l'indigent et à quiconque me les demandera. Je ne me laisserai pas influencer par la soif du gain ou la recherche de la gloire.

Admis(e) dans l'intimité des personnes, je tairai les secrets qui me seront confiés. Reçu(e) à l'intérieur des maisons, je respecterai les secrets des foyers et ma conduite ne servira pas à corrompre les mœurs.

Je ferai tout pour soulager les souffrances. Je ne prolongerai pas abusivement les agonies. Je ne provoquerai jamais la mort délibérément.

Je préserverai l'indépendance nécessaire à l'accomplissement de ma mission. Je n'entreprendrai rien qui dépasse mes compétences. Je les entretiendrai et les perfectionnerai pour assurer au mieux les services qui me seront demandés.

J'apporterai mon aide à mes confrères ainsi qu'à leurs familles dans l'adversité. Que les hommes et mes confrères m'accordent leur estime si je suis fidèle à mes promesses ; que je sois déshonoré(e) et méprisé(e)

si j'y manque.

99 